\title{
AKTIFITAS TABIR SURYA DENGAN NILAI SUN PROTECTION FACTOR (SPF) SEDIAAN LOSION KOMBINASI EKSTRAK KAYU MANIS DAN EKSTRAK KULIT DELIMA PADA PAPARAN SINAR MATAHARI DAN RUANG TERTUTUP
}

\author{
Youstiana Dwi Rusita, Indarto A.S \\ Kementerian Kesehatan Politeknik Kesehatan Surakarta Jurusan Jamu
}

\begin{abstract}
SPF, Kayumanis, Pomegranate, Lotions. The Sun produces ultraviolet radiation that causes damage to the skin texture, premature aging, burning skin reactions and skin cancer in exposed skin in a long period. One of the ways to protect skin from UV radiation use sunscreen lotions. Stem bark of cinnamon (Cinnamomun burmani) and pomegranate peel (Punica granatum) is known as an antioxidant activity and have a compound that is potentially as sunscreens. This research aims to know the activity of sunscreen with an SPF value of sunscreen lotions of pomegranate peel and cinnamon extract and the warming rays of the Sun and closed space. The determination of the value of the sun protection factor is done with methods of in vitro in Mansur using spectrophotometer UV-Vis. SPF Value calculated based on the Absorbance at a wavelength of 290-320 $\mathrm{nm}$. The result is a non parametric Test is analyzed using MannWhitney test. Results of organoleptic the colored is yellow brown, like to emultion and shaped the distinctive, smell of cinnamon, less homogeneous, showed the value of $\mathrm{pH}$ 5.63, dispersive power $6 \mathrm{~cm}$, adhesion 1.75 seconds and viscosity 5,500 cps. Preparations that are exposed in the Sunlight showed the value of SPF 20.146 whereas preparations stored in enclosed space showed the value of SPF 26.398. The results of statistical tests indicate that there is no difference between the SPF on preparations that are exposed to sunlight and in a closed space with alpha value $>0.05$.
\end{abstract}

Keywords: SPF, Kayumanis, Pomegranate, Lotions

Abstrak : SPF, Kayumanis, Delima, Losion. Sinar matahari menghasilkan radiasi ultra violet yang menyebabkan kerusakan pada tekstur kulit, penuaan dini, reaksi kulit terbakar dan kanker kulit apabila kulit terpapar dalam jangka waktu lama. Salah satu cara untuk melindungi kulit dari radiasi sinar ultra violet yaitu menggunakan losion tabir surya. Kulit batang kayu manis (Cinnamomun burmani) dan kulit buah delima (Punica granatum) diketahui memiliki aktivitas sebagai antioksidan dan memiliki senyawa yang berpotensi sebagai tabir surya. Penelitian ini bertujuan untuk mengetahui aktivitas tabir surya dengan nilai SPF pada sediaan losion tabir surya dari ekstrak kayumanis dan ekstrak kulit delima pada pemanasan sinar matahari dan ruang tertutup. Penentuan nilai sun protection factor dilakukan dengan metode Mansur secara in vitro menggunakan spektrofotometer UV Vis. Nilai SPF dihitung berdasarkan Absorbansi pada panjang gelombang 290-320 nm. Hasilnya dianalisis Uji non parametrik dengan menggunakan uji Mann-Whitney. Hasil uji organoleptik berwarna coklat kekuningan berbentuk emulsi dan berbau khas kayu manis, kurang homogen, menunjukkan nilai pH 5,63, daya sebar $6 \mathrm{~cm}$, daya lekat 1,75 detik dan viskositas 5.500 
cp. Sediaan yang dipanaskan di sinar matahari menunjukkan nilai SPF 20,146 sedangkan sediaan yang disimpan di ruang tertutup menunjukkan nilai SPF 26,398. Hasil uji statistika menunjukkan bahwa tidak ada perbedaan nilai SPF pada sediaan yang terpapar sinar matahari dan di dalam ruang tertutup dengan nilai alpha $>0,05$.

Kata Kunci : SPF, Kayumanis, Delima, Losion

\section{PENDAHULUAN}

Tabir surya adalah suatu zat atau material yang dapat melindungi kulit terhadap radiasi sinar ultra violet. Efektivitas sediaan tabir surya didasarkan pada penentuan nilai Sun Protection Factor (SPF) yang menunjukkan kemampuan produk tabir surya dalam melindungi kulit dari paparan sinar UV (Stanfield, 2003). Besar kecilnya nilai SPF dipengaruhi oleh kandungan antioksidan dari bahan aktif yang digunakan untuk membuat sediaan tabir surya. Antioksidan merupakan suatu zat yang dapat menetralkan radikal bebas sehingga melindungi tubuh dari berbagai macam penyakit dengan cara mengikat radikal bebas. Radikal bebas merupakan molekul sangat reaktif yang dapat merusak sel dan salah satu bentuk dari senyawa oksigen reaktif yang memiliki elektron tidak berpasangan (Winarsi, 2007). Radikal bebas dengan jumlah yang berlebih akan merusak kolagen pada membran sel kulit, sehingga kulit kehilangan elastisitasnya dan akan menyebabkan terjadinya keriput. Sinar UV merupakan gelombang elektromagnetik yang terdiri dari sinar UV-A (315-400 nm), sinar UV-B (290$315 \mathrm{~nm})$, dan sinar UV-C (100-290 nm) yang sangat berbahaya, memiliki energi yang sangat tinggi dan bersifat karsinogenik (Kaur et al., 2009).

Menurut penelitian Molyneux, (2004) salah satu sumber antioksidan alami terdapat pada kulit batang kayu manis. Kulit batang kayu manis mengandung senyawa yang memiliki aktivitas sebagai antioksidan yang kuat yaitu sinamaldehid. Tanaman lain yang memiliki aktivitas antioksidan yaitu kulit buah delima. Ekstrak kulit buah delima mengandung senyawa flavonoid dan tanin (Madrigal et al., 2009) serta bijinya mengandung senyawa fenolik untuk ellagitannins kompleks sebagai kegiatan antioksidan (Li He et al., 2011).

Bentuk sediaan yang dipilih losion, karena dapat tersebar tipis dibandingkan dengan sediaan krim atau salep dan dapat mencakup ke area kulit yang luas. Losion merupakan sediaan kosmetik berupa emulsi yang mengandung air lebih banyak dari minyak dan memiliki sifat sebagai sumber pelembab bagi kulit, lembut dan mudah dioleskan. Stabilitas produk merupakan pertimbangan yang terpenting bagi emulsi di bidang farmasi dan kosmetika. Kestabilan fisik dari emulsi farmasi memiliki ciri-ciri tidak adanya penggabungan fase dalam, tidak adanya creaming, dan memberikan penampilan yang menarik (Martin dkk., 1993).

Kondisi lingkungan lainnya seperti adanya cahaya, udara dan kontaminasi mikroorganisme, dapat memberikan efek yang mengubah stabilitas emulsi (Ansel, 1989). Nilai SPF pada sediaan yang langsung terpapar dengan matahari atau pada ruang tertutup akan menunjukkan adanya pengaruh terhadap cahaya pada sediaan tersebut. Penelitian ini juga ingin mengetahui 
apakah ada perbedaan nilai SPF pada sediaan losion tabir surya yang diberi paparan sinar matahari langsung maupun pada ruang tertutup.

\section{METODE PENELITIAN}

Rancangan penelitian yang digunakan dalam penelitian ini adalah rancangan observasi eksperimental. Losion dari ekstrak Kayumanis dan ekstrak kulit buah delima diuji fisik dan uji nilai SPF pada perlakuan dengan paparan sinar matahari dan ruang tertutup dengan menggunakan spektrofotometer Uv Vis. Perbandingan nilai SPF pada sediaan dengan paparan sinar matahari dan ruang tertutup dianalisis secara statistik menggunakan SPSS versi 16 dengan uji Mann-Whitney pada taraf kepercayaan $95 \%$.

\section{HASIL PENELITIAN}

Hasil uji fisik sediaan losion tabir surya kombunasi ekstra kayumanis dan ekstrak kulit buah delima yaitu pada tabel di bawah ini

Tabel 1

\begin{tabular}{|c|c|c|}
\hline \multicolumn{3}{|c|}{$\begin{array}{c}\text { Hasil Uji Fisik Losion Tabir Surya } \\
\text { Ekstrak Kayu Manis Dan Ekstrak } \\
\text { Kulit Delima }\end{array}$} \\
\hline Jenis Uji & & Hasil \\
\hline Organoleptik & $\begin{array}{l}\text { Wa } \\
\text { rna }\end{array}$ & :Coklat kekuningan \\
\hline & $\begin{array}{l}\text { Ben } \\
\text { tuk }\end{array}$ & : Emulsi \\
\hline Homogenitas & Bau & $\begin{array}{l}\text { : Khas Kayumanis } \\
\text { : kurang homogen, ada } \\
\text { partikel } \\
\text { tapi menyebar }\end{array}$ \\
\hline $\mathrm{pH}$ & & $: 5,63$ \\
\hline Daya Sebar & & $: 6 \mathrm{~cm}$ \\
\hline Daya Lekat & & : 1,75 detik \\
\hline Viskositas & & $: 5.500 \mathrm{cps}$ \\
\hline
\end{tabular}

Uji faktor pelindung surya dari sediaan losion kombinasi ekstrak kulit batang kayu manis dan kulit buah delima dilakukan secara in vitro menggunakan spektrofotometer UV-Vis dengan etanol 96\% sebagai blangko. Penentuan efektivitas sediaan tabir surya dilakukan dengan cara formula ditimbang sebanyak 1 gram dioleskan merata pada kaca obyek kemudian diberi penyinaran dibawah sinar matahari selama 60 menit sedangkan sampel kedua disimpan di dalam ruang tertutup dan gelap. Sampel dilarutkan dalam etanol $70 \%$ hingga $50 \mathrm{ml}$, lalu dipipet $1 \mathrm{ml}$. Selanjutnya diukur serapan larutan menggunakan spektrofotometer UV-Vis setiap $5 \mathrm{~nm}$ pada rentang panjang gelombang 290-320 nm untuk menentukan faktor pelindung surya (Pissavini dan Ferrero, 2004). Nilai SPF dihitung dengan rumus metode Mansur (1986):

$$
\begin{aligned}
& A=-\log 10 \frac{1}{S P F}=\log 10 S P F \\
& \mathrm{SPF}=10^{\mathrm{A}}
\end{aligned}
$$

Keterangan :

$$
\mathrm{A}=\text { Absorbansi }
$$

Tabel 2

Nilai Paparan Sinar Matahari Dan Di Dalam Ruang Tertutup

\begin{tabular}{ccccc}
\hline Panjang & \multicolumn{2}{c}{ Paparan Sinar Matahari } & \multicolumn{2}{c}{ Ruang Tertutup } \\
\cline { 2 - 5 } Gelombang & $\begin{array}{c}\text { Absorban } \\
\text { si }\end{array}$ & Nilai SPF & $\begin{array}{c}\text { Absorbans } \\
\text { i }\end{array}$ & Nilai SPF \\
\hline 290 & 2,02 & 100 & 2,027 & 106,414 \\
295 & 1,233 & 16,98 & 1,476 & 29,922 \\
300 & 0,967 & 9,26 & 1,26 & 18,197 \\
305 & 0,837 & 6,87 & 1,099 & 12,56 \\
310 & 0,558 & 3,614 & 0,905 & 8,035 \\
315 & 0,382 & 2,41 & 0,736 & 5,445 \\
320 & 0,278 & 1,89 & 0,625 & 4,217 \\
\hline rata-rata & & 20,15 & & 26,40 \\
\hline
\end{tabular}

Berdasarkan nilai SPF dari sediaan

tabir surya yang terpapar sinar matahari dengan nilai SPF 20,15 sedangkan yang 
disimpan pada ruang tertutup nilai SPF yaitu 26,40. Sesuai dengan tabel keefektifan sediaan tabir surya berdasarkan nilai SPF (Wilkson \& Moore, 1982) sediaan losion masuk dalam kategori proteksi ultra karena nilainya $\geq$ 15.

Hasil penelitian ini kemudian di analisis normalitas data dengan uji Shapiro-Wilk, nilai yang diperoleh alpha $<$ 0,05. Dilanjutkan dengan uji non parametrik dengan dua sampel bebas dengan menggunakan uji Mann-Whitney dengan nilai alpha $>0,05$ yaitu 0,259 . Hal ini menunjukkan bahwa tidak ada perbedaan nilai SPF sediaan yang diberi perlakuan dengan paparan sinar matahari dan di dalam ruang tertutup.

\section{PEMBAHASAN}

Uji organoleptik dari sediaan losion kombinasi ekstrak kulit batang kayu manis dan kulit buah delima meliputi bentuk warna dan bau ketika diaplikasikan ke kulit formulasi tersebut menghasilkan warna coklat kekuningan berbentuk emulsi dan bau khas kayu manis.

Uji homogenitas dari sediaan losion kombinasi ekstrak kulit batang kayu manis dan kulit buah delima diperoleh hasil tidak homogen, karena masih terdapat partikel-partikel coklat di dalam formulasi tersebut. Hal ini dapat dipengaruhi oleh faktor seperti ketepatan suhu untuk peleburan, dan pengadukan. Selain itu homogenitas losion ini juga dipengaruhi oleh ekstrak kayumanis dan ekstrak kulit delima yang tidak bercampur secara merata dan homogen pada saat pencampuran

Uji pH dari sediaan losion kombinasi ekstrak kulit batang kayu manis dan kulit buah delima yaitu 5,63.
Sehingga dapat disimpulkan bahwa losion aman diaplikasikan ke kulit karena $\mathrm{pH}$ yang terlalu asam dapat mengiritasi kulit sedangkan $\mathrm{pH}$ yang terlalu basa dapat membuat kulit bersisik (Naibaho, et al., 2014).

Daya sebar sediaan losion yang baik antara 5-7 cm (Ulaen, et al., 2012). Hasil pengukuran daya sebar ialah $6 \mathrm{~cm}$. Hal ini bisa dipengaruhi oleh konsentrasi setil alkohol yang digunakan, karena setil alkohol bersifat menaikkan viskositas dari sediaan sehingga daya sebar akan turun seiring kenaikan konsentrasi setil alkohol dalam sediaaan. Sehingga sediaan losion memenuhi standar.

Pengujian daya lekat dari sediaan losion kombinasi ekstrak kulit batang kayu manis dan kulit buah delima dilakukan untuk mengetahui kekuatan losion melekat pada kulit. Daya lekat losion menunjukkan hasil 1,7 detik. Hal ini dipengaruhi dari penggunaan setil alkohol dan asam stearat. Setil alkohol lebih berpengaruh besar terhadap kenaikan daya lekat dibanding asam stearat, kenaikan ini disebabkan karena kenaikan konsentrasi setil alkohol mampu menaikan viskositas, sehingga semakin meningkatnya viskositas maka daya lekat juga semakin meningkat. Sehingga penambahan konsentrasi setil alkohol akan mempengaruhi daya lekat losion. Daya lekat dari sediaan losion dikatakan sudah memenuhi syarat daya lekat yang baik yaitu kurang dari 4 detik (Ulaen, et al., 2012).

Pengujian viskositas dari sediaan losion kombinasi ekstrak kulit batang kayu manis dan kulit buah delima dilakukan di Laboratoruim Universitas Islam Negeri Sunan Kalijaga Yogyakarta menggunakan instrumen viscometer brookfield ${ }^{\circledR}$ menunjukkan hasil viskositas 
yaitu $5.500 \mathrm{cps}$. Viskositas yang baik dari sediaan losion berkisar 3.000 sampai 12.000 centipoise (cps) (Reich, 2011 dalam Dewi, 2014). Hal ini dipengaruhi dari $\mathrm{Na} \mathrm{CMC}$ yang digunakan karena konsentrasinya meningkatkan kekentalam dari sediaan losion.

Menurut Wilkinson dan Moore (1982), hal-hal yang diperlukan dalam tabir surya adalah efektif dalam menyerap sinar eritmogenik pada rentang panjang gelombang 290-320 nm tanpa menimbulkan gangguan yang akan mengurangi efisiensinya atau yang akan menimbulkan toksik atau iritasi.

Tingginya nilai SPF pada sediaan losion disebabkan karena kombinasi dari ekstrak kayumanis dan ekstrak kulit delima yang mempunyai manfaat yang sama. Metode maserasi tidak akan merusak senyawa yang ada sehingga kandungan flavanoid masih terjaga. Menurut Koirewoa, et al tahun 2013, Proses ekstraksi tidak dilakukan dengan metode soxhlet karena dikhawatirkan ada golongan senyawa flavanoid yang tidak tahan panas, selain itu senyawa flavanoid mudah teroksidasi pada suhu yang tinggi.

Berdasarkan hasil absorbansi mendapat nilai SPF paling tinggi pada panjang gelombang $290 \mathrm{~nm}$, sesuai menurut Markham (2008) flavonoid berjenis flavonon memilki daerah pita serapan maksimum pada rentang 275-295 $\mathrm{nm}$ pada Pita I dan 300-330 nm.

Nilai SPF yang dihasilkan dengan perbedaan perlakuan yaitu dengan sinar matahari langsung dan di dalam ruangan tertutup apakah ada beda dimana hal tersebut mempengaruhi aktivitas sebagai tabir surya suatu sediaan losion ekstra kayu manis dan ekstrak kulit delima. Melihat dari nilai SPF berbeda tetapi dengan analisis SPSS dengan tingkat kepercayaan 95\% memberikan hasil tidak ada beda.

\section{KESIMPULAN DAN SARAN}

Nilai SPF sediaan losion tabir surya dari ekstrak kayumanis dan ekstrak kulit buah delima termasuk kategori ultra dan tidak ada perbedaan aktivitas tabir surya pada paparan sinar matahari dan pada ruang tertutup.

\section{DAFTAR RUJUKAN}

Ansel, H.C. 1989. Pengantar Bentuk Sediaan Farmasi, Edisi Keempat. Jakarta : UI Press.

Dewi, A. K., 2013. Isolasi, Identifikasi dan Uji Sensitivitas Staphylococcus aureus terhadap Amoxicillin dari Sampel Susu Kambing Peranakan Ettawa (PE) penderita mastitis di wilayah girimulyo kulonprogo yogyakarta, Jurnal Sain Veteriner, 31 (2), 143-145.

Kaur J, et al. (2009). Differential roles played by the native cysteine residues of the yeast glutathione transporter, Hgt1p. FEMS Yeast Res 9(6):849-66

Koirewoa, Y.A., Fatimawali, F., \& Wiyono, W.I. 2012. Isolasi dan identifikasi senyawa flavonoid dalam daun beluntas (Pluchea indica L.). Pharmacon 1 (1): 4752.

Li He, Honggao Xu, Xuan Liu, Wenhao $\mathrm{He}$, Fang Yuan, Zhanqun Hou, Yanxiang Gao. 2011. Identification of phenolic compounds from pomegranate (Punica granatum L.) seed residues and investigation into their antioxidant capacities by HPLC- 
ABTS +assay. Food Research International. 44:1161-1167.

Madrigal S. Carballo, G. Rodriguez, C.G. Krueger, M.Dreher, J. D Read (2009). Pomegranate (Punicagranatum) supplements : authenticity antioxidant and polyphenol composition. Journal of functional Food.

Mansur JS, Breder MNR, Mansur MCA, Azulay RD.1986. Determination of Sun Protection Factor for Spectrophotometry. An Bras Dermatol Rio De Janeiro, 61, 1214

Markham, K.R.Andersen, O.M., 2006, Flavonoid, Chemistry, Biochemistry and Application,. 2, CRC Press, United State

Martin, A., Swarbick, J., dan A. Cammarata. 1993. Farmasi Fisik 2. Edisi III. Jakarta: UI Press

Molyneux, P. 2004. The use of stable free radical Dhiphenylpicryhydarzyl (DPPH) for estimating antioxidant activity, songklanakarin J.Sci. Technol., 2004, 26(2) : 211-219

Naibaho, O.H., Yamlean, P.V., Wiyono, W. 2013. Pengaruh basis salep terhadap formulasi sediaan salep ekstrak daun kemangi (Ocinum sanctum) Pada kulit punggung kelinci yang dibuat infeksi Staphylococcus aureus. Jurnal Ilmiah Farmasi Vol. 2 No. 02 hal 27-33. UNSRAT.

Pissavini, M., \& Ferrero, L. (2004). In Vitro Determination of Sun Protection Faktor. Chemist and Head Sun Product Research, International Research \& Development Center, 1-5.
Stanfield, J.W. 2003. Sun protectans : enhancing prodduct functionality with sunscreeens, in schueeller, r. and romanowski, p. multifunctional cosmetic. New York : Marcel Dekker Inc

Ulaen, S. P. J., Banne, Y., Suatan., dan Ririn, A. 2012. Pembuatan salep anti jerawat dari ekstrak rimpang temulawak (Curcuma xanthorrhiza Roxb). Jurnal Ilmiah Farmasi Vol 3 No 2 ..

Wilkinson, J. B. dan Moore, R. J., 1982, Harry's Cosmeticology, 7thEd., 223-224, 236.

Winarsi, H. 2007. Antioksidan Alami dan Radikal Bebas. Yogyakarta : Kanisius. 